\section{To: (Receiving Organization)}

Distribution

5. Proj./Prog./Dept./Div.:

W78B8 Corrosion Probe Development

8. Originator Remarks:

This document satisfies the requirements of Milestone B1 of TTP\# RL0-8-WT-21.

11. Receiver Remarks: 11A. Design Basel ine Document? [X] Yes [] No

Design of second-generation corrosion monitoring probe.
3. From: (originating Organization)

TWRS Life Extension Equipment Engineering (74711)

6. Design Authority/ Design Agent/Cog. Engr.:

G. L. Edgemon
4. Related EDT No.: 624075

7. Purchase Order No.:

N/A

9. Equip./Component No.:

$\mathrm{N} / \mathrm{A}$

10. System/Bldg./Facility: $\mathrm{N} / \mathrm{A}$

12. Major Assm. Dwg. No.: N/A

13. Permit/Permit Application No.: $N / A$

14. Required Response Date; $N / A$

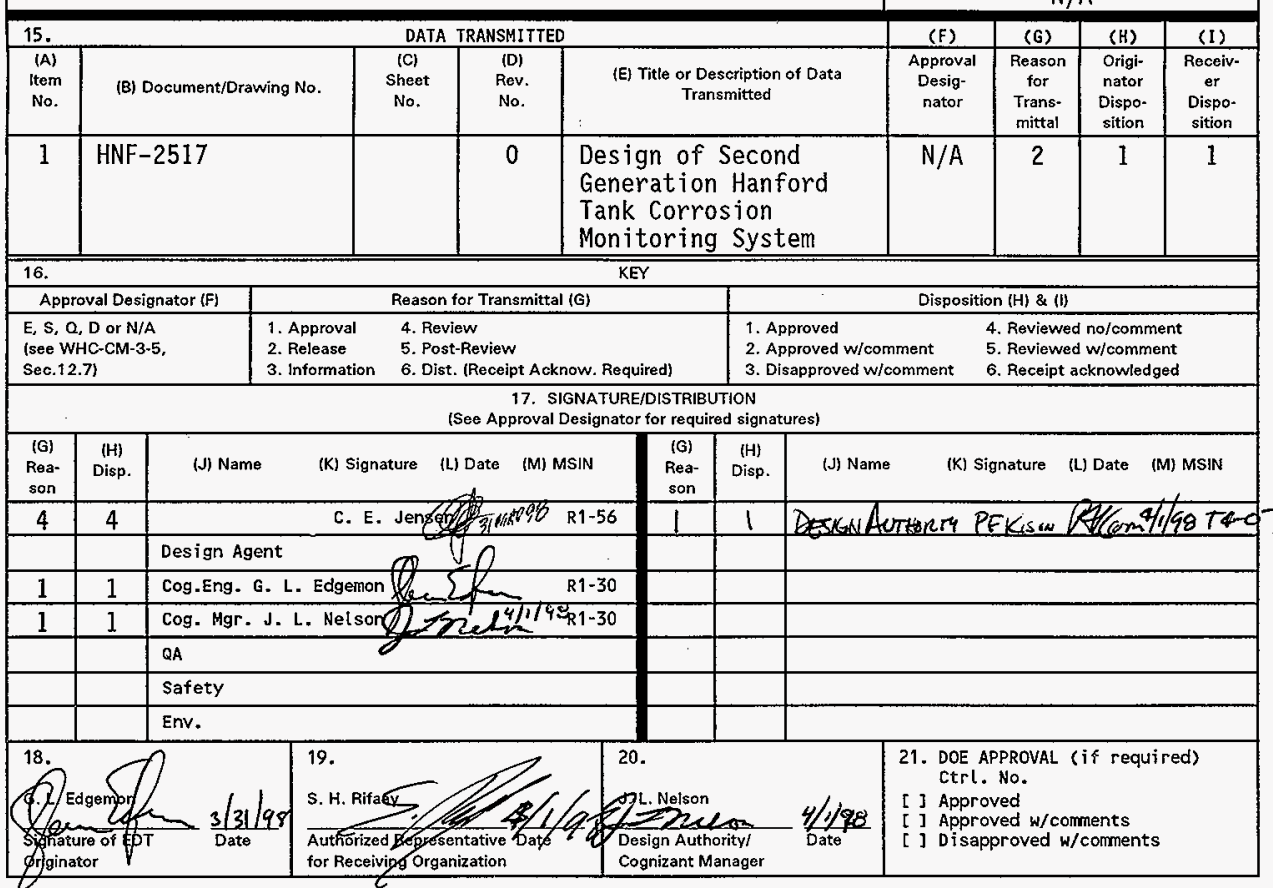

BD-7400-172-2 (05/96) GEF097 


\title{
Design of Second Generation Hanford Tank Corrosion Monitoring System
}

\author{
G. L. Edgemon, J. L. Nelson
}

Lockheed Martin Hanford Corporation, Richland, WA 99352

U.S. Department of Energy Contract DE-ACO6-96RL13200

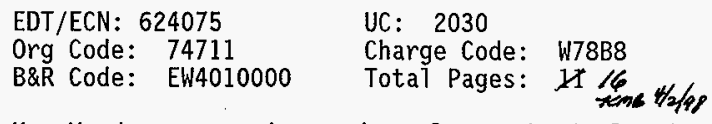

Key Words: corrosion probe, electrochemical noise

Abstract: This document describes the design of the second generation corrosion monitoring system for Hanford waste tanks and satisfies

Milestone B1 of TTP\# RL0-8-WT-21.

TRADEMARK DISCLAIMER. Reference herein to any specific comercial product, process, or service by trade name, trademark, manufacturer, or otherwise, does not necessarily constitute or imply its endorsement, recommendation, or favoring by the United States Government or any agency thereof or its contractors or subcontractors.

Printed in the United States of America. To obtain copies of this document, contact: Document Control Services, P.0. Box 950, Mailstop H6-08, Richland WA 99352, Phone (509) 372-2420;

$\operatorname{Fax}(509) 376-4989$.
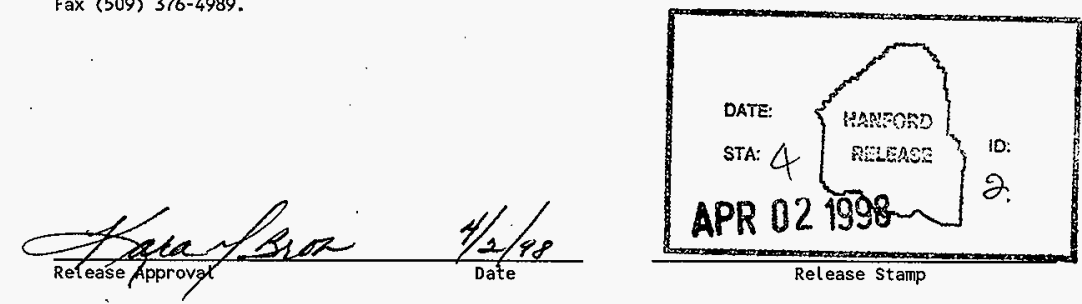

Approved for Public Release 


\title{
Design of Second Generation Hanford Tank Corrosion Monitoring System
}

\author{
G. L. Edgemon \\ J. L. Nelson \\ Lockheed Martin Hanford Corp.
}

Date Published

April 1998

Prepared for the U.S. Department of Energy Assistant Secretary for Environmental Management

Fluor Daniel Hanford, Inc.

P.O. Box 1000

Richland, Washington 


\section{Introduction and Background}

The Hanford Site has 177 underground waste tanks that store approximately 253 million liters of radioactive waste from 50 years of plutonium production [1]. Twenty-eight (28) tanks have a double shell and are constructed of welded ASTM A537-Class 1 (UNS K02400), ASTM A515-Grade 60 (UNS K02401), or ASTM A516-Grade 60 (UNS K02100) materia1. The inner tanks of the doubleshel] tanks (DSTS) were stress relieved following fabrication. One hundred and forty-nine (149) tanks have a single shel1, also constructed of welded mild steel, but not stress relieved following fabrication. Tank waste is in liquid, solid, and sludge forms. Tanks also contain a vapor space above the solid and liquid waste regions. The composition of the waste varies from tank to tank but generally has a high $\mathrm{pH}(>12)$ and contains sodium nitrate. sodium hydroxide, sodium nitrite, and other minor radioactive constituents resulting from plutonium separation processes [1-4]. Leaks began to appear in the single-shell tanks shortly after the introduction of nitrate-based wastes in the 1950s. Leaks are now confirmed or suspected to be present in a significant number of single-shell tanks [1]. The probable modes of corrosion failures are reported as nitrate stress corrosion cracking (SCC) and pitting [2].

Previous efforts to monitor internal corrosion of waste tank systems have included linear polarization resistance (LPR) and electrical resistance techniques [5-6]. These techniques are most effective for monitoring uniform corrosion, but are not well suited for detection of localized corrosion (pitting and SCC). The Savannah River Site (SRS) investigated the characterization of electrochemical noise (EN) for monitoring waste tank corrosion in 1993. but the tests were not conclusive [7]. The SRS effort has recently been revived and additional testing is underway.

For many years, EN has been observed during corrosion and other electrochemical reactions, and the phenomenon is well established, [8-19]. Typically. EN consists of low frequency $(<1 \mathrm{~Hz})$ and small amplitude signals that are spontaneously generated by electrochemical reactions occurring at corroding or other surfaces [20]. Laboratory studies and recent reports on field applications have reported that EN analysis is well suited for monitoring and identifying the onset of localized corrosion, and for measuring uniform corrosion rates [14-26]. A two year laboratory study was started at Hanford in 1995 to provide a technical basis for using EN in Hanford nuclear waste tanks [27]. Based on this study, a prototype system was constructed and deployed in DST 241-AZ-101 in August, 1996 [28]. Based on the successful demonstration of this prototype for more than a year, a first-generation full-scale system was designed and installed into DST 241AN-107 in September 1997 [29]. This document summarizes the design and operational requirements of the second-generation ful1-scale system scheduled 
for deployment into 241-AY-102 in late 1998 as required by Milestone Number B1 of TTP RL0-8-WT -21.

\section{System Design and Configuration}

The 241-AY-102 monitoring system is designed, like most EN based corrosionmonitoring systems, to measure instantaneous fluctuations in corrosion current and potential between three nominaliy identical electrodes (a working, a counter, and a pseudo-reference electrode) of the material of interest immersed in the environment of interest. Time-dependent fluctuations in corrosion current between the working and counter electrodes are described by electrochemical current noise. Time-dependent fluctuations of the difference in the corrosion potential between the working/counter electrode assembly and the pseudo-reference electrode are described by electrochemical potential noise. Since a zero resistance ammeter (ZRA) electrically joins the working and counter electrodes, potential differences are measured between the working/counter electrode assembly and the pseudoreference electrode. It has been shown that each type of corrosion phenomenon presents a unique relationship between corrosion current and potential transients in the temporal data [8-29]. Other methods of analysis involve transforming temporal data to the frequency domain for analysis [30]. As of the time of the preparation of this report, no frequency analysis of the EN data from the 241-AY-102 system is expected. However, statistical analysis techniques will be employed.

Tank 241-AY-102 has been selected to receive waste from tank 241-C-106 in fiscal year 1998 or 1999. The 241-AY-102 corrosion monitoring system is designed to detect the onset of localized corrosion phenomena if tank conditions should change to allow these phenomena to occur as a result of this waste transfer. Based on the operation of the prototype 241-AZ-101 system and the first-generation 241-AN-107 corrosion monitoring system. the following design goals were established for the tank-intrusive portion of the 241-AY-102 corrosion monitoring system:

1. The probe shall be fabricated from materials capable of providing at least five years of service

2. The maximum diameter of the probe must remain small enough to fit through 10.2-cm diameter riser

3. The probe design shall facilitate decontamination by minimizing areas of liquid retention such as cracks, crevices, hard angles, rough surfaces, etc.

4. All materials and overall design should be capable of withstanding temperature ranges up to $100^{\circ} \mathrm{C}$

5. All materials and overall design should be capable of withstanding liquid phase pH ranges from 7 to 14 
6. Al1 materials and overall design should be capable of withstanding radiation levels up to $1000 \mathrm{R} / \mathrm{hr}$

7. All materials and overall design should be capable of withstanding liquid phase flow rates up to $1.0 \mathrm{~m} / \mathrm{s}$

8. The conductor/feed-through connections shall be improved to better withstand probe flexure during mixer pump operation

9. The probe design should facilitate the insertion of up to four thermocouple locations at various tank depths

The following performance requirements were established for the ex-tank data collection electronics:

1. When connected to an appropriate set of electrodes, the corrosion monitoring equipment. must be capable of collecting current and voltage electrochemical noise (EN) data in an automated fashion (i.e.: once configured, the system should continuously collect EN data unless interrupted by the user). Specifically, the equipment must be capable of making simultaneous measurements of both current and voltage EN at a recording rate of at least one (1) measurement per second. The equipment must be capable of making measurements on at least eight channels simultaneously. Multiplexed systems that read sequentially from channel to channel are not acceptable.

2. In addition to being capable of collecting and analyzing EN data, the system must also be capable of periodically conducting linear polarization resistance (LPR) and Tafel scans. The corrosion monitoring system and system software must allow this periodic change. Preferably, the system will be configurable to allow the user to set up a time interval between LPR scans. For example, the system could be configured to collect EN data continuous7y, but once per month, stop the EN measurements, call out and run an LPR scan on each channel, then return to EN measurements.

3. The physical location of the waste tanks in relation to power sources, phone lines. network drops and other necessary connections dictates that there will be up to 400 feet $(\sim 122 \mathrm{~m})$ of 20 -gauge wiring between the lowermost channels on the probe and the corrosion monitoring instrumentation. Each wire (one wire per channel) will pass through an MTL Model 755-AC shunt-diode type intrinsic safety barrier before passing into the corrosion probe body and down to its respective electrode. The maximum entity parameters for the MTL Model 755-AC barriers are 40 microfarads capacitance and 0.125 millihenry inductance. The length of wiring from the barriers to the electrodes will be 100 feet $(\sim 31 \mathrm{~m})$ or less. The balance of the wiring runs from the intrinsic safety barriers to the corrosion monitoring instrumentation. With the long cable and intrinsic safety barriers in place, the system must be capable of current 
and potential resolutions of at least $\pm 1 \times 10^{-9} \mathrm{~A}$ and $\pm 1 \times 10^{-5} \mathrm{~V}$ respectively. Prior to contract award, the seller will be required to show evidence that their equipment meets these minimum sensitivity requirements given the aforementioned set-up.

4. The in-tank corrosion probe that holds the electrodes in the waste is designed for eight total channels with three electrodes on each channel. The corrosion probe is fabricated from 1.0 -inch $(2.5-\mathrm{cm})$ diameter schedule XXS stainless steel pipe with an inside diameter just large enough to contain 24 conductors of 20-gauge wire. The corrosion monitoring instrumentation must utilize a three wire per channel, eight-channel setup with simple 20-gauge wires, as opposed to shielded coaxial cables, to make the connection between electrodes and instrument.

5. The software that controls the corrosion monitoring system shall be compatible with standard desktop computer operating platforms. All EN and LPR data must be stored in a format compatible with ODBC and SQL databases to allow the user to export data to other user supplied analyses and presentation packages. Furthermore the corrosion monitoring system software shall be capable of performing and graphically presenting statistical analyses on the EN data, automaticaliy calculating corrosion rates. from LPR data, and calculating and presenting trends in the statistical analyses data. The corrosion monitoring system software must provide user configurable alarm points to notify the user of the onset of dangerous corrosion conditions within the waste tank. The software shall be configurable to allow full storage of all data all the time or to automaticaily discard data not recorded at a set interval of time on either side of an. alarm event, thus minimizing the amount of EN data the user must evaluate.

Based on these requirements a probe design was selected and an EN based hardware/software package was ordered in March 1998. The majority of the in-tank portion of the probe is constructed from $2.5-\mathrm{cm}$ diameter schedule XXS AISI 304L stainless steel (UNS 30403) pipe for extended service in the waste tank environment. It fits through a nominal $10.2-\mathrm{cm}$ diameter tank riser and is approximately $16.2 \mathrm{~m}$ in length. The top $61-\mathrm{cm}$ of the probe is constructed of 9.5-cm diameter AISI 304L piping filled with low density concrete to serve as a shield plug for the riser. A detailed drawing of the probe body is shown in Appendix A.

The probe has four two channel electrode arrays. Arrays are positioned at $6.0 \mathrm{~m}, 10.3 \mathrm{~m}, 12.8 \mathrm{~m}$, and $15.5 \mathrm{~m}$ from the top of the riser. The eight total channels will allow corrosion monitoring in the vapor space and the supernate phase of the tank. Each channel on the probe utilizes three nominally identica? electrodes of either a C-ring (ASTM G-38) or pin type geometry 
constructed of archived ASTM A537-Class. 1 tank steel (leftover from the 241-AP farm construction). Each C-ring electrode exposes approximately $44 \mathrm{~cm}^{2}$ of surface area to the waste. Pin type electrodes will expose approximately $10-44 \mathrm{~cm}^{2}$ of surface area to the waste. Different pin sizes may be inserted to study the effects of probe electrode size on data sensitivity. One electrode of each C-ring array will be pre-cracked by cyclic fatigue and strained beyond the proportional limit just prior to immersion in the waste to assist in monitoring stress corrosion cracking should it occur. Precracks are approximately $0.5 \mathrm{~mm}$ in depth. The other electrodes wi 11 not be strained.

A 25-conductor full-shielded data cable extends through the length of the interior of the sealed pipe. At each electrode array, three conductors are removed from the shielding and attached to commercially available glass-lined feed-throughs, one conductor per feed-through. Glass-7ined feed-throughs are used to penetrate the probe tree pipe wall while maintaining electrical isolation between the electrodes and the pipe wall. Each glass feed-through is mounted in a short length of AISI 304L stainless steel bar stock which has been seal welded to the probe body at a $45^{\circ}$ angle. This configuration should improve the ability of the conductor/feed-through connections to withstand probe flexure during mixer pump operation. Electrodes are isolated from the glass to metal seals through the use of peroxide cured ethylene propylene (EPDM) gaskets suitable for use in radiation environments. Some of the feedthroughs utilize a modified seating surface in an effort to improve the seal between the electrode and the feed-through. The performance of the unmodified glass feed-throughs will be compared with the performance of the modified feed-throughs in an effort to optimize the sealing surface without causing excessive crevice corrosion problems.

A11 conductors running from the 24 electrodes run up the inside of the probe body and terminate at the top to the probe in a weather tight box. Aboveground cabling utilizes a grounded shield to protect the signal from external electrical interference and will use shunt-diode type intrinsic safety barriers to meet site safety requirements for waste intrusive instrumentation. In addition to EN electrode cabling running up the interior of the probe body, four separate stainless stee] sleeved thermocouples will run from the probe flange at the top of the tank to the detectors situated along the probe body. Thermocouples will be affixed to the exterior surface of the probe body. A thermocouple will terminate at each detector to allow waste temperature data to be collected at detector depths within the tank.

The data collection software/hardware system procured for the secondgeneration system is an Amulet system manufactured by Corrosion \& Condition 
Control, Ltd. ${ }^{1}$ The system is capable of collecting current and voltage EN data in an automated fashion on eight channels simultaneously. The system can be configured to collect EN data continuously, but periodically stop the EN measurements, call out and run an LPR scan on each channel, then return to EN measurements. Current and potential resolutions of at least $\pm 1 \times 10^{-9} \mathrm{~A}$ and $\pm 1 \times 10^{-5} \mathrm{~V}$ respectively on long cable lengths passing through intrinsic safety barrier systems are possible with the system. The instrument configuration supports a three wire per channel, eight-channel setup with simple 20-gauge wires. The system software runs on a Microsoft Windows '95 or Windows NT platform and stores data in a format compatible with ODBC and SQL databases. ${ }^{2}$ The operating software is capable of performing and graphically presenting statistical analyses on the EN data, automatically calculating corrosion rates from LPR data, and calculating and presenting trends in the statistical analyses data. The corrosion monitoring system software provides user configurable alarm points to notify the user of the onset of dangerous corrosion conditions within the waste tank. The software is configurable to allow full storage of all data all the time or to automatically discard data not recorded at a set interval of time on either side of an alarm event, thus minimizing the amount of EN data the user must evaluate.

\section{Summary and Conclusions}

A second-generation EN based corrosion monitoring system has been designed and will be fabricated and installed into double-shel1 waste tank 241-AY-102 at the Hanford Site in late 1998 . In relation to the first-generation system installed in 241-AN-107, several improvements and modifications have been incorporated into the design of the second generation system including:

1. The conductor/feed-through connections are positioned on $45^{\circ}$ angles to improve their ability to withstand probe flexure during mixer pump operation. The conductor/feed-through connections on the first-generation probe were made on $90^{\circ}$ angles and were more difficult to fabricate and are more susceptible to failure during probe flexure. By using $45^{\circ}$ angle connections, more space will be available for extra wire necessary to allow for probe flexure during mixer pump operation.

2. The second-generation probe design facilitates the insertion of at least four thermocouple locations at various tank depths. The first-generation design had no thermocouples.

\footnotetext{
1 Amulet is a registered trademark of Corrosion \& Condition Control Ltd., Dingwall, RossShire, UK

2 Windows, Windows '95, and Windows NT. are registered trademarks of Microsoft Corporation. Redmond, Washington
} 
3. Different pin sizes will be inserted to study the effects of probe electrode size on data sensitivity. Data being generated by the first generation probe indicates that the sma.17 $5-\mathrm{cm}^{2}$ pins may be too small to generate optimal EN signal back to the instrumentation.

4. Different glass feed-through designs will be tested to learn which.design minimizes crevice formation between electrode and gasket. The firstgeneration design uses the modified glass feed-throughs on all C-ring electrodes. At least one set of C-ring electrodes on the secondgeneration probe will utilize flat seating surfaces in an effort to check for crevice formation on the modified seating surfaces.

5. Data will be collected simultaneously on eight channels. The firstgeneration and prototype systems utilized multiplexed data collection. The use of multiplexed systems results in long gaps in data on a given channel while data are collected on the remaining channels.

6. The system can be configured to automatically collect EN data continuously with periodic LPR scans at user configurable intervals. LPR scans on the prototype and first-generation systems must be done manually.

7. The operating software is capable of automatically performing and graphically presenting statistical analyses on the EN data, automatically calculating corrosion rates from LPR data, and calculating and presenting trends in the statistical analyses data. Statistical analysis, plotting. and corrosion rate analysis on data sets from the first-generation probe must be done manualiy.

8. The corrosion monitoring system software provides user configurable alarm points to notify the user of the onset of dangerous corrosion conditions within the waste tank. The first-generation system provides no alarm points. Data analysis must be done manually to identify any dangerous periods of corrosion activity.

9. The software is configurable to allow full storage of all data all the time or to automatically discard data not recorded at a set interval of time on either side of an alarm event, thus minimizing the amount of. EN data the user must evaluate. The first generation system stores all data until manually sorted by the operator. 
HNF-2517, REV. 0

\section{References}

[1] P.C. Oh], J.D. Thomson, and F.R. Vollert, Corrosion Considerations for Life Management of Hanford. High Level Waste Tanks, CORROSION/94, paper no. 142, (Houston, TX: NACE Internationa1, 1994).

[2] D.C. Lini, Compilation of Hanford Corrosion Studies, Atlantic Richfield Hanford Company Report, ARH-ST-111, UC-70, July, 1975.

[3] J.R. Divine, W.M. Bowen, D.B. Mackey, D.J. Bates, and, K.H. Poo], Prediction Equations for Corrosion Rates of A537 and A516 Steels in Double She11 Slurry, Future PUREX, and Hanford Facilities Wastes, Pacific Northwest Laboratory Report, PNL-5488, June, 1985.

[4] W.C Carlos, Recommendations for Erosion/Corrosion Allowance for MultiFunction Waste Tank Facility Tanks, CORROSION/95, paper no. 449, (Houston, TX: NACE International, 1995).

[5] J.L. Nelson, Hanford DST Corrosion Monitoring Instrument Tree, CORROSION/95, paper no. 440, (Houston. TX: NACE Internationa1, 1995).

[6] R.K. Shuk7a, A.J. Perkins, P.M. Bourgeois, R.J. Jaramins; W.G. Secen, and, D.J. Stroud, Corrosion Monitoring of High Level Waste Storage Tank 8-D2 at the West Valley Demonstration Project, CORROSION/94, paper no. 121. (Houston. TX: NACE Internationa1, 1994).

[7] J.I. Mickalonis, R.J. Jacko, G.P. Quirk, and D.A. Eden, in: Proc. First Int. Symposium on Electrochemical Noise Measurements for Corrosion Applications, ASTM STP 1277, eds. J.R. Kearns, J.R. Scully, P.R. Roberge, D.L. Reichert, and J.L. Dawson, (American Society for Testing and Materials, Philadelphia, PA, 1996) p. 201.

[8] T. Haygard and J. R. Williams, Trans. Farad. Soc. 57, (1961): p. 2288.

[9] P. Bindra, et a1., Discussions of Faraday Soc. 56, (1974): p. 189.

[10] M. Fleischmann, et al., Surface Science 100-101, (1980): p. 583.

[11] G.J. Bignold and M. Fleischmann. Electrochemical Acta 19, (1974): p. 363.

[12] E. Budevski, et a1., Electrochemical Acta 28, (1983): p. 925.

[13] G. Blanc, et al., Electrochemical Acta 23, (1978): p. 337. 
[14] K. Hladky and J. L. Dawson, Corrosion Science 22, (1982): p. 231.

[15] D.A. Eden, J.L. Dawson, and D.G. John, U.K. Patent Application 861158, May 1986. U.S. Patent 5139627.

[16] K. Hladky, European Patent 084404A3, U.S. Patent 455709, Canadian Patent 418938.

[17] U. Bertocci, Electrochemical Noise Analysis and Its Application to Corrosion, CORROSION/89, paper no. 24, (Houston, TX: NACE Internationa?, 1989).

[18] J.L. Dawson, D.M. Farre11, P.J. Aylott, and K. Hladky, Corrosion Monitoring Using Electrochemical Noise Measurements, CORROSION/89, paper no. 31, (Houston, TX: NACE International, 1989).

[19] D.A. Eden, A. N. Rothwe17, and J.L. Dawson, "Electrochemical Noise for Detection of Susceptibility to Stress Corrosion Cracking. CORROSION/91. paper no. 444. (Houston, TX: NACE Internationa 1, 1991).

[20] D.M. Farrel1, Industrial Corrosion 9, (1991): p. 7.

[21] A.N. Rothwel1. T.G. Walsh, and W.M. Cox, On Line Corrosion Investigation and Surveillance - Chemical Plant Case Studies. CORROSION/91, paper no. 170, (Houston, TX: NACE Internationa 1, 1991).

[22] J.L. Dawson, et al., On-line Monitoring of Continuous Process Plants, ed. D. Butcher, (Ellis Horwood, NY, 1983).

[23] D.M. Farre11, W.M. Cox, and D. Gearey, Multi-System Corrosion Monitoring in a Cyclic Reheat Test Facility; Phase 1, Electric Power Research Institute Report. CS-5776, 1988.

[24] D.M. Farrel1, W.M. Cox and D. Gearey, Multi-System Corrosion Monitoring in FGD Systems; Phase 2, Electric Power Research Institute Report, CS$5734,1988$.

[25] B.C. Syrett and W.M. Cox, in: Proc. First Int. Symposium on Electrochemical Noise Measurements for Corrosion Applications. ASTM STP 1277, eds. J.R. Kearns, J.R. Scully, P.R. Roberge, D.L. Reichert, and J.L. Dawson. (American Society for Testing and Materials, Philadelphia, PA, 1996) p. 173.

[26] C.A. Lotto and R.A. Cottis, Corrosion 45, (1989): p. 136. 
[27] G.L. Edgemon and G.E.C. Be11, Technical Basis for Electrochemical Noise Based Corrosion Monitoring of Underground Nuclear Waste Storage Tanks, Westinghouse Hanford Company Report, WHC-SD-WM-TI-772, November, 1996.

[28] G.L. Edgemon, J.L. Nelson, P.C. Oh1, and G.E.C. Bel1, Hanford Prototype Corrosion Probe Operational Experience, CORROSION/97, paper no. 97124. (Houston. TX: NACE International, 1997).

[29] G.L. Edgemon, J.L. Nelson, and G.E.C. Bell, Design of an Electrochemical Noise Based Corrosion Monitoring Probe for High Level Nuclear Waste Storage Tanks, CORROSION/98, paper no. 98175, (Houston. TX: NACE Internationa 1,1998 ).

[30] L. Beaunier, J. Frydman, C. Gabrielli, F. Huet, and M. Keddam, in: Proc. First Int. Symposium on Electrochemical Noise Measurements for Corrosion Applications, ASTM STP 1277, eds. J.R. Kearns, J.R. Scully, P.R. Roberge, D.L. Reichert, and J.L. Dawson, (American Society for Testing and Materials, Philadelphia, PA, 1996) p. 114. 


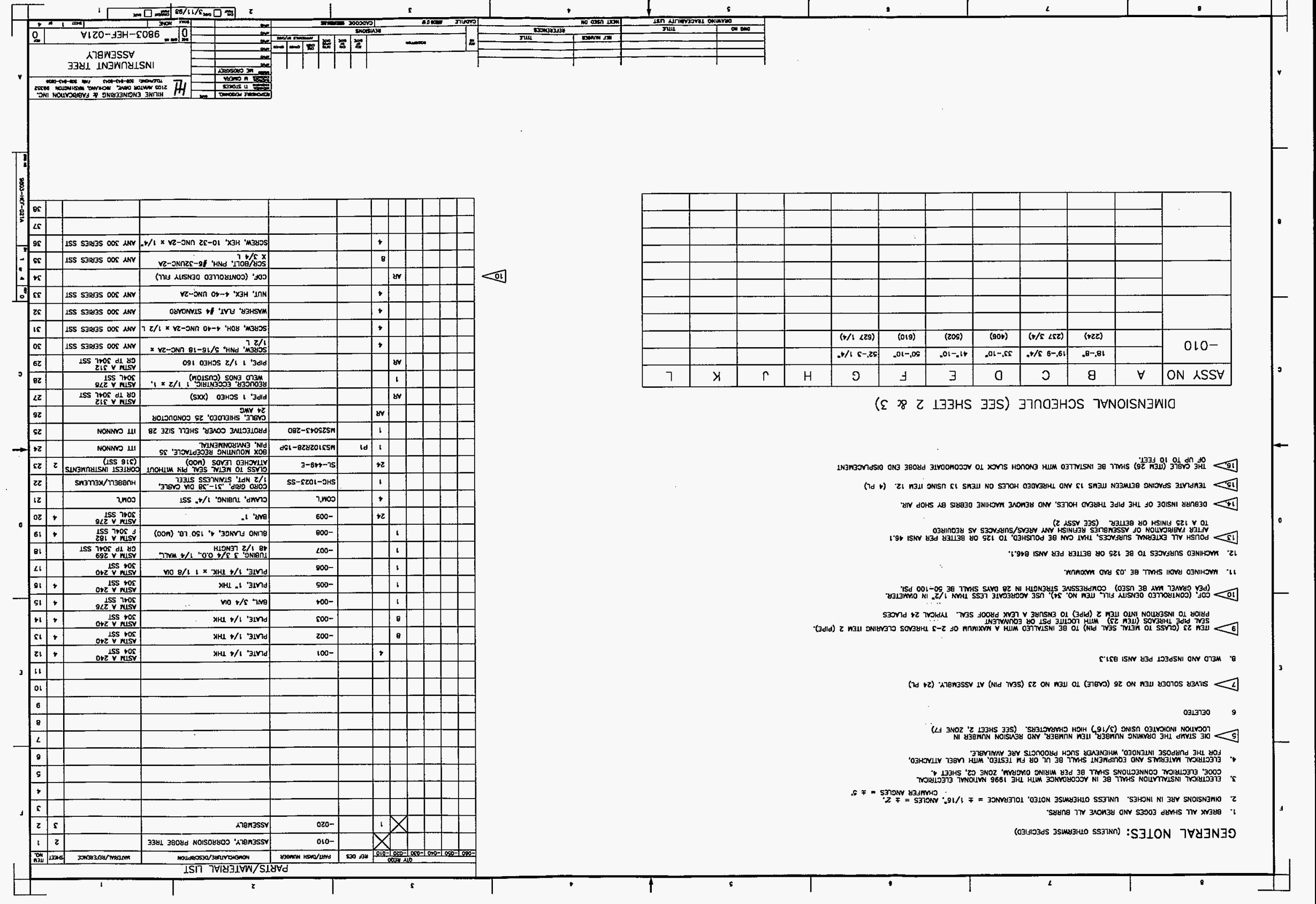




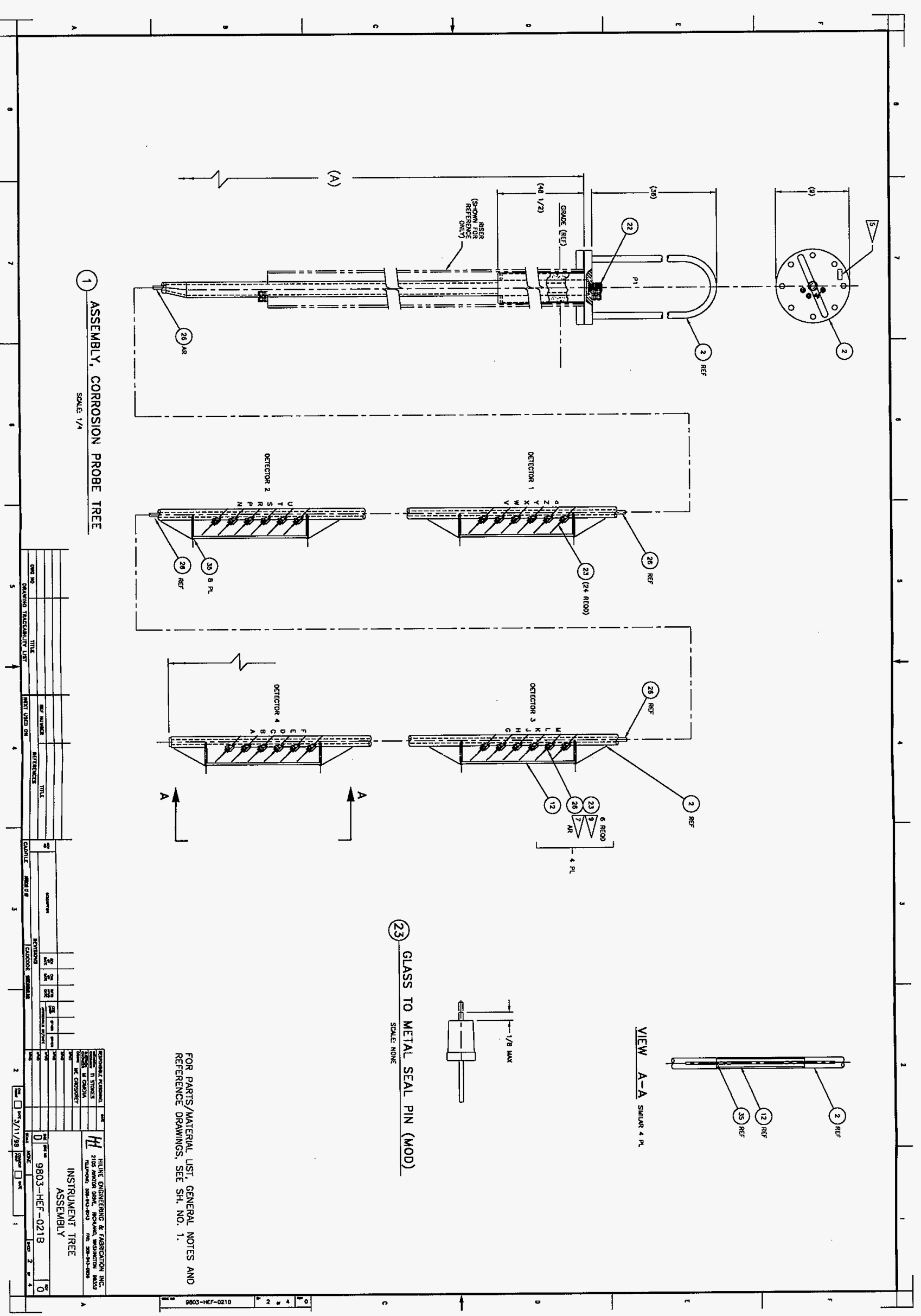




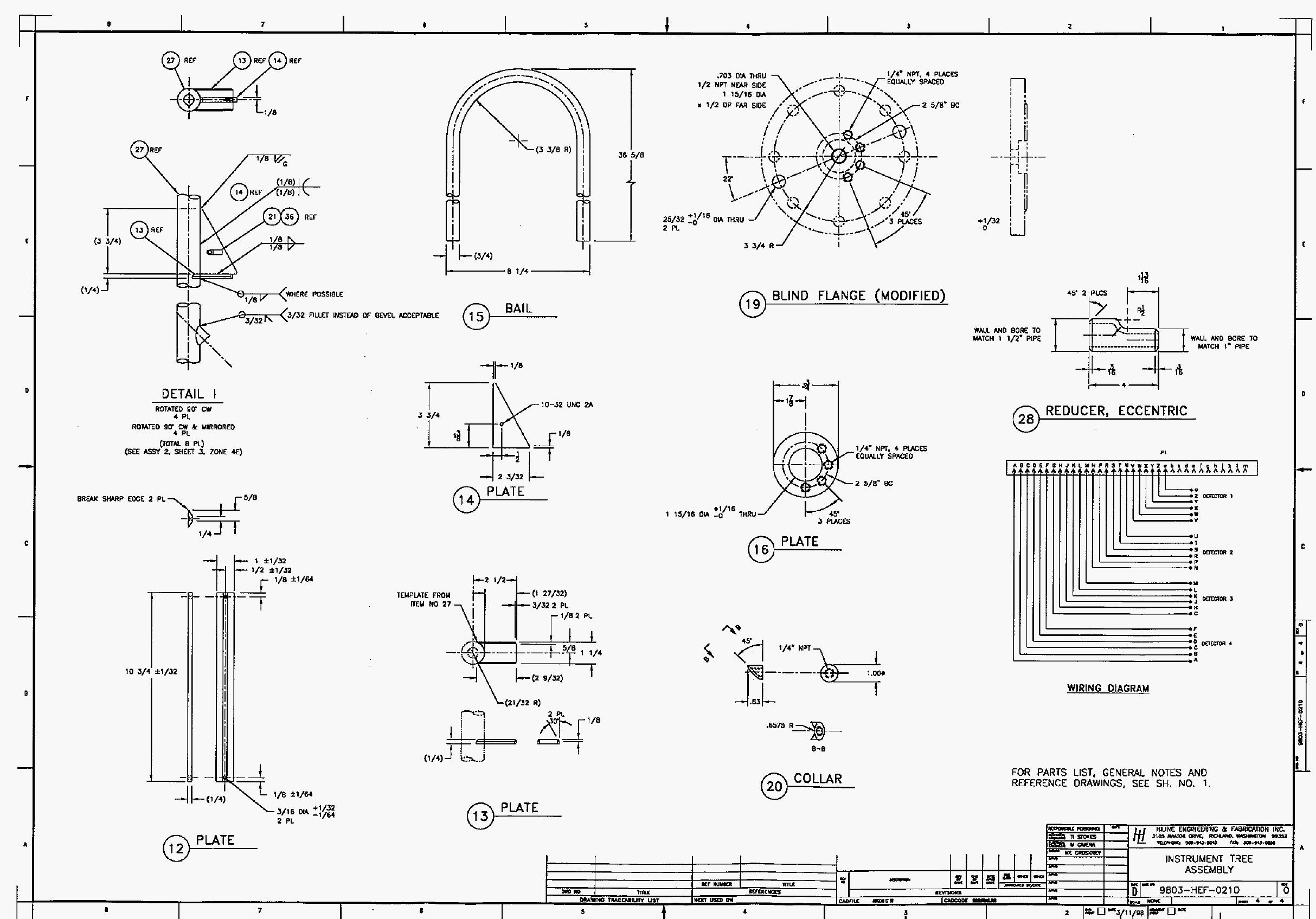




\section{DISTRIBUTION SHEET}

\begin{tabular}{|c|c|c|c|c|c|}
\hline \multirow{2}{*}{$\begin{array}{l}\text { To } \\
\text { Distribution }\end{array}$} & \multirow{2}{*}{\multicolumn{3}{|c|}{$\begin{array}{l}\text { From } \\
\text { Life Extension Equipment } \\
\text { Engineering }\end{array}$}} & \multicolumn{2}{|l|}{ Page 1 of 2} \\
\hline & & & & \multicolumn{2}{|c|}{ Date Apri1 1, 1998} \\
\hline \multicolumn{4}{|l|}{ Project Title/Work Order } & \multicolumn{2}{|c|}{ EDT No. 624075} \\
\hline \multicolumn{4}{|c|}{$\begin{array}{l}\text { Design of Second Generation Hanford Tank Corrosion Monitoring } \\
\text { System }\end{array}$} & \multicolumn{2}{|l|}{ ECN No. $N / A$} \\
\hline Name & MSIN & $\begin{array}{c}\text { Text } \\
\text { With All } \\
\text { Attach. }\end{array}$ & Text Only & $\begin{array}{l}\text { Attach./ } \\
\text { Appendix } \\
\text { Only }\end{array}$ & $\begin{array}{l}\text { EDT/ECN } \\
\text { Only }\end{array}$ \\
\hline Central Files & A3-88 & $x$ & & & \\
\hline $\begin{array}{l}\text { Tanks Focus Area Field Lead } \\
\text { c/o J. A. Frey }\end{array}$ & $k 8-50$ & $x$ & & & \\
\hline G. L. Edgemon & $\mathrm{R} 1-30$ & $\times(5$ & copies) & & \\
\hline G. T. Frater & K9-46 & $x$ & & & \\
\hline M. J. Glaspar & $k 8-50$ & $x$ & & & \\
\hline J. 0. Honeyman & G3-2I & $x$ & & & \\
\hline P. F. Kison & $T 4-07$ & $x$ & & & \\
\hline C. E. Jensen & R1-56 & $x$ & & & \\
\hline c. S. Louie & A6-54 & $x$ & & & \\
\hline J. L. Nelson & $R 1-56$ & $x$ & & & \\
\hline $\begin{array}{l}\text { Tanks Focus Area Technical Team } \\
\text { c/o G. C. Notch }\end{array}$ & K9-69 & $x<\varepsilon$ & copies) & & \\
\hline M. L. Ramsay & $S 7-54$ & $x$ & & & \\
\hline
\end{tabular}

\section{OFFSITE}

L. H. Sullivan

Safety Technology Integration Mangager Los Alamos National Laboratory

P. 0. Box 1663

Los Alamos, NM 87545

$\mathrm{X}$

P. E. Woodal1

U. S. Department of Energy

Idaho Operations office

750 DOE P7ace MS: 1145

Idaho Fal1s, ID 83402

A. M. Jensen

Lockheed Martin Idaho Technologies Company

P. 0. Box 1625 MS: 3204

Idaho Fa17s, ID 83415-3204 
J. R. Noble-Dial

U. S. Department of Energy

Oak Ridge Operations Office

P. 0. Box 2001

Oak Ridge, TN 37830-8620

$x$

S. M. Robinson

Martin Marietta Energy Systems, Inc,

Oak Ridge National Laboratory

P. 0. Box 2008 MS: 6044

Oak Ridge, TN 37831

$\mathrm{X}$

T. S. Gutmann

U. S. Department of Energy

Savannah River Operations office

P. 0. Box A

Aiken, SC 29802

$x$

J. P. Morin

Westinghouse Savannah River Company

Savannah River Technology Center

703-H Bldg.

Aiken, SC 29808

$x$ 